\title{
Micro Propagation of Banana, and its Role in Africa
}

\section{Fatudimu Olanrewaju Jephthah*}

\author{
FHMC Nigeria, Nigeria
}

*Corresponding Author: Fatudimu Olanrewaju Jephthah, FHMC Nigeria, Nigeria.

Received: June 17, 2019; Published: June 27, 2019

DOI: 10.31080/ASAG.2019.03.0551

\section{Introduction}

Banana production in Africa is constrained by factors such as limited availability of quality planting material to help overcome this challenges, researches has been promoting and facilitating access to new high yielding, pest and disease resistant improved hybrid banana cultivars with good consumer acceptability. As prelude to the wide scale distribution of these hybrids, macro - propagation technology is promoted for the production of healthy planting material. The objective of micro propagation production is to develop a cost - effective and sustainable system for continuous multiplication and timely distribution of quality planting materials.

\section{The theory}

Plant tissue culture is the science of growing plant cell, tissue or organs isolated from the mother plant, an artificial media.

It includes techniques and methods appropriate to research into many botanical disciplines and several practical objectives. Both organized and unorganized growth is possible in vitro.

\section{Scaling up}

Before banana seedlings can be planted in the field, the plantlets produced by laboratories need to be weaned and hardened. The plantlets are weaned by putting them in a humidity chamber until they are $4-5 \mathrm{~cm}$ tall, then placed in large bags and hardened in a shaded nursery until they are $20-50 \mathrm{~cm}$ tall. The plantlets are free of bacteria and fungi, but they can carry viruses. Intensive testing is needed to be reasonably confident that the plantlets are virus free. But once on field, bananas can be easily re-infected with disease. Research suggests, weeding, watering and extra fertilizer to strengthen the plant, it also recommends removing the male bud of the plant (to prevent bees and other insects from foraging for pollen in the male flower, which can infect the plant with bacteria wilt).

Why we need improved species in Nigeria

The growing urban market are making bananas a more important source of cash for small holders about $26 \%$ of the population depends on bananas for food and income in rural areas and about $65 \%$ of city people cooked bananas every day. Burundi is a NCT importer, bringing in bananas from Rwanda and Tanzania and beer bananas from Tanzania and DR. Congo. Kenya imports cooking and dessert banana from Uganda and Tanzania.

Kenya also exports some bananas to the Middle East and the European Union. Uganda exports some of it bananas to DR. Congo, South Sudan, Kenya and Rwanda, and to a niche market of East African emigrants in Europe and the USA.

\section{Results in Africa}

TC nurseries and laboratories had established over 30 nursery businesses in Uganda and Kenya, making supplies of banana seedlings available for farmers. A cost benefit analysis of nurseries in Uganda revealed profit of about $\$ 0.25$ per plant, which increased as more plants were sold, trainings were assessed on 87 farmers field over two crop cycles in Burundi and Uganda, revealing a doubling in yield for farmers who grew banana and received training compared with control farmers.

\section{Volume 3 Issue 7 July 2019 \\ C All rights are reserved by Fatudimu Olanrewaju Jephthah.}

